\title{
Otel Çalışanlarında Tükenmişlik ve İşten Ayrılma Niyetine Etkisi: Bişkek'te Bir Araştırma ${ }^{1}$
}

\author{
Zhyldyz TEMIRKANOVA² ve Lütfi ATAY ${ }^{3}$
}

\section{Özet}

Tükenmişlik sendromu yaşamın her alanında görülebilecek bir durumdur. Özellikle müşteri ilişkisi yoğun, üretim ile tüketimin eş zamanlı olduğu turizm sektörü için tükenmişlik önemli bir etkiye sahiptir. Turizm sektöründe önemli payı olan ve işgücü devir hızı yüksek olan konaklama işletmelerin başarısında önemli rol oynayan etkenlerden birisi de işten ayrılma niyetidir. Bu nedenle otel yöneticilerinin işletmenin başarısı için çalş̧anların tükenmişlik sendromunu tespit etmesi, önlemesi ve işten ayrılma niyetlerinin önüne geçmesi gerekmektedir. Kırgızistan'ın Bişkek şehrindeki otellerde çalışanların tükenmişlik düzeylerini tespit etmek ve işten ayrılma niyetine etkisini incelemek amacıyla bu çalışma tasarlanmıştır. Bişkek'te faaliyet gösteren otellerde çalşan toplam 277 çalş̧andan anket formu aracilığı ile toplanan veriler SPSS paket programı kullanılarak analiz edilmiştir. Araştırmada otel çalışanlarının genel tükenmişlik düzeyleriyle işten ayrılma niyeti arasında istatistiksel olarak anlamlı bir ilişki tespit edilmiştir. Ayrıca, çalışanların duygusal tükenmişlik ve duyarsızlaşma düzeyleri ile işten ayrılma niyetleri arasında pozitif yönlü bir iliş̧i tespit edilmiştir.

Anabtar Kelimeler: Tükenmişlik Sendromu, İşten Ayrilma, Bişkek Otelleri

Hotel Employee Burnout and the Influence on the Intention for Voluntary Resignation: A Survey in Bishkek

\begin{abstract}
The burnout syndrome is a condition that can be observed in any area of life. Burnout has an important effect especially for the tourism sector where customer relationship is intense and production \& consumption are simultaneously. One of factors that plays an important role in the success of the accommodation enterprises, which have an important share in the tourism sector and have a high turnover rate, is the intention for voluntary resignation. This prompts the hotel management teams to detect and prevent the burnout syndrome among employees, eliminating the reasons for voluntary resignation. The main purpose of this study is to investigate the effect of the burnout syndrome and the tendency for voluntary resignation at hotels in Bishkek, Kyrgyzstan. Data has been obtained from 277 hotel employees at three, four and five star hotels via survey form tool. The data obtained from the survey has been studied and analyzed though SPSS package program. In the study, a statistically significant relationship was found between the intentions to quit the general burnout levels of the employees. A positive correlation was determined between emotional burnout \& depersonalization levels of employees and their intention to quit.
\end{abstract}

Key Words: Burnout Syndrome, Voluntary Resignation, Bishkek Hotels

\section{Atıf İçin / Please Cite As:}

Temirkanova, Z. ve Atay, L. (2021). Otel çalışanlarında tükenmişlik ve işten ayrılma niyetine etkisi: Bişkek’te bir araştırma. Manas Sosyal Araștırmalar Dergisi, 10(2), 1423-1435.

Geliş Tarihi / Received Date: 14.11.2020

Kabul Tarihi / Accepted Date: 08.01.2021

1 Yüksek lisans tezinden üretilmiştir

2 ÇOMÜ Sosyal Bilimler Enstitüsü Turizm İşletmeciliği Yüksek Lisans Mezunu

(iD) ORCID: 0000-0002-9870-959X

${ }^{3}$ Doç. Dr. - ÇOMÜ Turizm Fakültesi Seyahat İşletmeciliği ve Turizm Rehberliği Bölümü

(iD) ORCID: 0000-0003-2598-6227 


\section{Giriş}

Günümüzde teknoloji hızla gelişmeye devam etmektedir ve yaşantımızda önemli yer almaktadır. İnsanların yaşamlarını kolaylaştırmak amacıyla icat edilen makinalar, insan işgücünün yerine geçmeye başlamıştır. Fakat turizm gibi bazı sektörlerde insan faktörü vazgeçilemez bileşenlerden birisidir. Genellikle üretildiği anda tüketilen turistik ürünün sunumu ciddi dikkat ve özveri gerektirmektedir. Bu nedenle insan ve hizmet odaklı turizm sektöründe iş stresinin yüksek olduğu söylenebilir. Dinlenme sonucunda geçmeyen stres tükenmişlik sendromuna yol açabilmektedir. Turizm sektöründe çalısanlar ücret, çalışma ortamı, çalışma şartları vb. iç ve dış faktörlere bağlı olarak tükenmişliğe maruz kalabilmektedir.

Tükenmişlik fiziksel, psikolojik ve davranışsal bazı olumsuz belirtiler şeklinde ortaya çıkabilmektedir. Tükenmişlik birçok olumsuz sonuçlara sebep olmaktadır. İşten ayrılma niyeti de tükenmişlik neticesi ortaya çıkabilmektedir. İşten ayrılma niyeti hem çalışanları hem de işletmeleri olumsuz yönde etkilemektedir. Bu olumsuzluklar; üretim kaybı, yeni personel bulma, personelin eğitimi için zaman kaybı, bireyler için gelir kaynağının kaybedilmesi ve yeni iş arama stresi şeklinde sıralanabilir. Tükenmişlik ve işten ayrılma niyeti ilişkisinin değişik meslek gruplarında, hem Türkçe hem de yabancı kaynaklarda araştırıldığı görülmektedir. Ancak, Kırgızca kaynaklarda otel çalışanlarında tükenmişlik ve işten ayrılma niyetine etkisi hakkında çalışmaya rastlanmamışıฺr. Söz konusu literatür eksiğini gidermeye yönelik bu araştırmanın temel amac1, Kırgızistan'ın başkenti Bişkek'te faaliyet gösteren otellerde çalışanların tükenmişlik ve işten ayrılma niyeti arasında ilişki olup olmadığını incelemektir. Turizmin gelişmekte olduğu Kırgızistan'ın başkentinde otel çalışanlarının tükenmişlik düzeyinin tespit edilmesinin, olası sorunların ortadan kaldırılmasına ve turizm politikalarının sağlıklı geliştirilmesine katk1 sağlayabileceği öngörülmektedir. Turizm sektörünün yeterince gelişmediği ve turizmde meslek yasalarının yetersiz olduğu Bişkek'te faaliyet gösteren otellerde çalışanların bu araştırmanın örneklemini oluşturması, literatürdeki diğer araştırmalardan farklılık olarak değerlendirilebilir.

\section{Literatür}

Tükenmişlik kavramının ilk kez 1974 yllında psikiyatrist Herbert Freudenberger tarafindan yayınlanan bir bilimsel çalışma ile literatüre girdiği ve Freudenberger'in tükenmişliği, "başarısız olma, yıpranma, aşırı yüklenme sonucu güç ve enerji kaybı veya karşılanamayan istekler sonucu bireyin iç kaynaklarında tükenme durumu" olarak tanımladığı ve herhangi bir nedenin sonucunda bireyi etkisiz hale getirdiğini tespit ettiği bilinmektedir (Aslan ve Etyemez, 2015, s. 484; Osmanoğlu Taştan, 2015, s. 18; Öztürk Çiftçi, Meriç, ve Meriç, 2015, s. 997; Sağlam Arı ve Çına Bal, 2008, s. 132; Sağlam Arı, Bal ve Çına Bal, 2010, s. 143; Ulutaş, 2015, s. 42;)

Cherniss (1980) tükenmişliği "aşırı bağll1k duygusu neticesinde meydana gelen aşırı stres ve doyumsuzluk kaynaklı geri çekilme" olarak ifade etmiştir (Ok, 2002, s. 18). Edelwich (1980) tükenmişlik sendromunu; "hizmet sektörü çalşsanlarının çalşsma koşullarının sonucunda idealizm, enerji ve tecrübelerinde bir azalma süreci” olarak değerlendirmiştir (Cemaloğlu ve Kayabaşı, 2007, s. 127).

Günümüzde tükenmişlik üzerine birçok çalışma yapılmış ve tükenmişlik kavramı ile ilgili tanımlar geliştirmiştir. Fakat Freudenberger'in çalışmasından sonra tükenmişlik kavramı ile ilgili çok sayıda bilimsel çalışması olan Christina Maslach, literatüre büyük bir katkı sağlayarak konuya ilişkin Maslach Tükenmişlik Ölçeği (MBI) geliştirmiştir. Bu nedenle tükenmişliğin en çok atıf alan ve kabul gören tanımının Maslach'a ait olduğu görülmektedir (Aslan, 2014, s. 22; Sağlam Arı ve Çına Bal, 2008, s. 132; Sağlam Ar1 vd., 2010, s. 145;). Maslach ve Jackson' un (1981) yapmıs olduğu tanımına göre tükenmişlik “işi gereği yoğun duygusal taleplere maruz kalan ve sürekli diğer insanlarla yüz yüze çalş̧ak durumunda olan kişilerde görülen fiziksel bitkinlik, uzun süreli yorgunluk, çaresizlik ve umutsuzluk duygularının, yapılan işe, yaşama ve diğer insanlara karşı olumsuz tutumlarla yansıması ile oluşan bir sendromdur" şeklinde ifade edilmektedir.

Konaklama işletmeleri dinamik, yorucu ve karmaşık yapılara sahiptir (Birdir ve Tepeci, 2003, s. 93; Etyemez, 2013, s. 4). Büyük ölçüde konaklama işletmelerin başarısı kendi işgücüne bağlıdır (Kaya, 2010, s. 220). Bu nedenle konaklama işletmeleri, kendi çalışanlarından işe odaklanmalarını ve kendilerini işe adamalarını bekleyebilmektedir. Yoğun çalışma temposunda turizm sektöründe çalışan tüm çalışanlar iç ve dış faktörlere (ücret, çalışma ortamı, kurum değerleri vb.) bağlı olarak strese, depresyona hatta tükenmişlik sendromuna maruz kalabilmektedir.

Kişiler ve örgütler bakımından negatif neticeleri olan ve işletmeler bakımından son derece önemli görülen tükenmişlik sendromu (Ardıç ve Polatçı, 2008, s. 74) özellikle, personel verimliliği, iş tatmini, 
kaliteli hizmet üretimi, mesleğe dair performans ve işe olan soğumalarda önemli bir faktör olarak öne çıkmaktadır. Tükenmişlik, turizm sektöründe çalısanlar ve faaliyetini devam ettirmekte olan işletmeler bakımından üstünde üzerinde durulması gereken bir konu olarak karşımıza çıkmaktadır (Üngüren, Doğan, Özmen, Tekin, 2010, s. 2925). Konaklama işletmelerinde çalışanların işten ayrılma oranının yüksek olması, sektöründeki en önemli sorunlardan birisidir (Kaya, 2010, s. 220). Bu nedenle tükenmişlik sendromunun turizm sektörü için önemini arttırmaktadır.

Tükenmişlik konusu ile ilgili pek çok araştırma mevcuttur ve araştırmalarda tükenmişliğe sebep olan nedenler ortaya konulmuştur. Tükenmişlik farklı nedenlerden ortaya çıabilmektedir, bu nedenler kişilere bağlı olabildiği gibi organizasyonlardan da kaynaklanabilmektedir. Hiçbir zaman tek başına bir sebepten dolayı tükenmişlik sendromu gerçekleşmemekte, birden fazla neden ve faktörden etkilenerek oluşmaktadır (Adoum, 2017, s. 17). Bu faktörler kişisel ve örgütsel faktörler başlıkları altında sinıflandırılabilir. Tükenmişliğe maruz kalan insanların bu durumuyla başa çıkılması için yapılan araştırmalarda tükenmişlik sendromuna etki eden bu faktörleri ortaya çıkarmaları önem arz etmektedir (Ardıç ve Polatc1, 2009, s. 23). Kişisel ve örgütsel sebeplerden başlıca olanları; yaş, medeni durum, cinsiyet gibi demografik özelliklerin yanında, çok yüksek kişisel beklentiler, işlerine olan bağlllık, mesleki doyum, özel hayattaki gerginlik, stres, motivasyon vb. pek çok özellik tükenmişliğe neden olan özelliklerin arasında daha sık görülmektedir (Izgar, 2003, s. 11).

Başka bir ülkeye yerleşme durumu işten ayrılma niyetini etkileyen bir faktör olarak görülmüştür. Cerdin ve Le Pargenux'a (2014, s. 2046) göre şirket veya herhangi bir kurumda çalışan bireyler, yurtdışına çıkıp edindikleri bilgiler ve kazandıkları tecrübeler doğrultusunda şirket veya kurum içinde saygınlıkları artacağını öngörmektedir. Yurtdışında bulunan bireylerin iş dünyasında başarısının daha fazla olması olasıllı̆̆ birey için bir motivasyon kaynağıdır. Her çalışanın bu durumu bir başarıya dönüştüremeyeceği dikkate alınırsa, bireyin yurtdışına çıtı̆̆ında verimliliğin her zaman artmayacağı da gözden kaçırılmamalıdır.

Çalışma kabiliyeti bireyin kurum içinde veya ekip içinde üzerine düşen görevleri yerine getirerek, gelecekte de bu konuda kendini geliştirebilmesi ihtimali olarak tanımlanabilir. Yapılan araştırmalar bireyin işten ayrılma niyetini, çalışma kabiliyetinin yüksek olmasının olumlu yönde etkilediğini tespit etmişlerdir (Austen v.d. 2016, s. 20). Bu doğrultuda çalışma kabiliyeti yüksek olan kişilerin, çalışma kabiliyeti düşük olan kişilere oranla daha az işten ayrllma eğiliminde oldukları görülmüştür

Çok sayıda araştırma bulgusu çalışanların tükenmişliğinin sebepsiz yere ve birden meydana gelen bir sendrom olmadığını ortaya koymaktadır. Tükenmişlik, çalışanın iş yerinde ve işi ile ilgili yaşadığı olumsuzlukların neticesinde ortaya çıkan bir sendrom olarak görülmektedir (Kervanc1, 2013, s. 33). Tükenmişliğin belirtileri çalışan kişilere göre farklllık göstermekte ve genellikte "fiziksel", "duygusal/bilişsel" ve "davranışsal" belirtiler olarak üç başlık altında toplanmaktadır (Ardıç ve Polatçı, 2008, s. 73; Çam, 1995, s. 17; Kervanc1, 2013, s. 33; Sağlam Ar1 ve Bal, 2008, s. 141; Sürgevil, 2014, s. 31).

Tükenme şevk ve coşku evresi, durağanlaşma evresi, engellenme evresi ve umursamazlık evreleri olmak üzere toplam dört evreden oluşmakta (Kaçmaz, 2005, s. 30) ve birçok olumsuz sonuçlara sebep olmaktadır. İşten ayrılma niyeti de tükenmişlik neticesi ortaya çıkabilmektedir. İşten ayrılma niyeti hem iş görenleri hem de işletmeleri olumsuz yönde etkilemektedir. Bu olumsuzluklar; üretim kaybı, yeni personel bulma, personelin eğitimi için zaman kaybı, bireyler için gelir kaynağının kaybedilmesi ve yeni iş arama stresi şeklinde sırlanabilir.

Çok sayıdaki yazara göre işten ayrılma sebebi veya niyeti istifa işareti olarak algılanmaktadır (Weisberg, 1994, s. 10). Elangovan'a (2001) göre bu durum "davranışsal bir yönelim, işi bırakma sürecinin algısal ifadesi şeklinde ifade edilebilmektedir (Elangovan, 2001, s. 159). İşten ayrllma niyeti, yeni iş veya işlere başvuruda bulunma, özgeçmişini ilgili kurumlara gönderme, mülakatlara katılma, gelen iş tekliflerini değerlendirerek kabul veya reddetme sürecini temsil etmektedir. Price ve Mueller (1986), işten ayrilma niyeti üzerine ise "bireyin çalıştığ kurumdan ayrrlma ihtimali" söyleminde bulunmuştur.

İşten ayrılma sebepleri üzerine farklı araştırmalar yapılmış, bu araştırmalarda farklı değişkenler ya da farklı örnek olaylar kullanılmıştır (Veloutsou, Lewis, Paton, 2004, s. 122). Şirket, kurum ya da örgüt içerisinde çalışan her bireyin bazı spesifik iş pozisyonları vardır. Ayrıca her birey iş kolunda belli bir öneme sahiptir. Bireyin çalıştı̆̆ kurumdan ayrılması halinde, bu kuruma bazı maliyetleri olur. Bu maliyet ve 
sıkıntıları; yeni çalışacak adayın bulunması ve bunun için harcanacak olan zaman ve kişinin işe alım sürecinde işi öğrenmesine yönelik alacağı eğitim olarak sıralamak mümkündür.

\section{Araştırmanın Hipotezleri ve Modeli}

Yapılan araştırmada konaklama işletmelerinde çalışanların tükenmişlik düzeyleri ile işten ayrılma niyeti arasında ilişkiye yönelik hipotezler ilgili literatürde yapılan çalışmalardan (Aslan, 2014; Aslan ve Etyemez, 2015; Etyemez, 2013; Öztürk Çiftçi,Meriç, Meriç, 2015; Yıldırım vd, 2014;) yola çıkılarak hipotezler oluşturulmuştur.

Yıldırım, Erul ve Kelebek (2014) banka çalışanlarına yönelik yaptığı araştırmasında tükenmişlik ile işten ayrılma niyeti arasında ilişkiyi tespit etmeye çalışmıştır. Gerçekleştirilmiş analizlerin sonucuna göre tükenmişlik ile işten ayrılma niyeti arasında pozitif yönlü bir ilişki bulunmuştur. Buradan yola çıkarak banka çalısanların tükenmişlik düzeyin arttığı zaman işten ayrılma niyeti oluşumu da artması beklenmektedir şeklinde yorumlanabilmektedir. Öztürk Çiftçi vd. (2015) örgütsel sessizlik, tükenmişlik ve işten ayrılma niyeti arasındaki ilişkileri belirlemek amacıyla yaptıkları çalışmada, tükenmişlik ile işten ayrılma niyeti arasında pozitif yönlü ve anlamlı bir ilişki tespit etmişlerdir. Bu sonuca göre tükenmişlik düzeyin artığında işten ayrılma niyetinin de artı̆̆1 söylemek mümkündür. Tükenmişlik ile işten ayrılma niyeti arasında pozitif bir ilişki olduğu başka çalışmalarda da görülmektedir (Jackson ve Maslach, 1982; Jackson, Schwab ve Schuler, 1986; Weisberg, 1994, s. 4, Schaufeli ve Backer, 2004, s. 293). Bu bilgiler 1şığında tükenmişlik ile işten ayrılma niyeti ilişkisine yönelik aşağıdaki hipotez oluşturulmuştur:

$\mathbf{H}_{1}$ : Bişkek’teki konaklama işletmelerinde çalışanların tükenmişlik düzeyleri ile işten ayrılma niyeti arasında bir ilişki vardır

Aslan'ın (2014) çalışmasında seyahat acentasında çalışanlara yönelik genel tükenmişlik ve tükenmişlik alt boyutlar ile işten ayrılma niyeti arasında bir ilişsinin olup olmadığını incelenmiştir. Araştırmanın sonucunda duygusal tükenme ile işten ayrilma arasında yüksek düzey pozitif bir ilişki tespit edilmiştir. Goodwin, Groth ve Frenkel (2011) da duygusal tükenmişliğin işten ayrrlma niyetini etkilediğini tespit etmiştir. Bu bağlamda duygusal tükenmişlik ile işten ayrılma niyeti arasındaki ilişkiye yönelik olarak aşağıdaki hipotez geliştirilmiştir:

$\mathbf{H}_{2}$ : Çalışanların duygusal tükenmişlik düzeyleri ile işten ayrılma niyetleri arasında pozitif yönlü bir ilişki vardır

Etyemez'in (2013) otel çalışanlarına yönelik duyarsızlaşma ile işten ayrılma niyeti arasında ilişkiyi belirlemek amacıyla gerçekleştirilen çalışmada, duyarsızlaşma ile işsten ayrilma niyeti arasında pozitif yönlü, anlamlı bir ilişki bulmuştur. Bu sonuçtan yola çıkarak, otel çalışanlarının duyarsızlaşmasının artmasına bağlı olarak işten ayrılma niyetinin ortaya çıktığı da söylenebilir. Aslan ve Etyemez’in (2015) gerçekleştirdikleri çalışmada otel çalışanlarının duyarsızlaşma ile işten ayrılma niyeti arasındaki ilişkiye bakılmıştır. Yapılan çalışmada duyarsızlaşma artarken işten ayrilma niyetinin de artığı sonucuna ulaşılmıştır. Duygusal tükenme bireyin işi ile kendisi arasına duygusal ve bilişsel mesafe koymasına neden olmakta, duyarsızlaşma durumunda ise işin gerektirdiği durumlar ile kendisi arasında bir duvar örmektedir. (Sweeney ve Summers, 2002, s.22). Bu bilgiler ışı̆̆ında duyarsızlaşma ile işten ayrılma niyeti arasındaki ilişkiye yönelik olarak aşağıdaki hipotez geliştirilmiştir:

$\mathbf{H}_{3}$ : Çalışanların duyarsızlaşma düzeyleri ile işten ayrılma niyetleri arasında pozitif yönlü bir ilişki vardır

Çalışkan ve Pekkan'ın (2019) 526 sağlık sektöründe çalışanları üzerinde tükenmişlik ile işten ayrılma arsında ilişkiyi belirlemek amacı ile yapılan çalışmada kişisel başarıda düşüş ile işten ayrılma niyeti arasında pozitif ve istatistiksel olarak anlamlı bir ilişki bulunmuştur. Bu sonuca göre kişisel başarıda düşüş düzeyi artığ1 zaman işten ayrılma niyetinin de artığı söylenebilir. Bu bağlamda kişisel başarıda düşüş ile işten ayrılma niyeti arasındaki ilişkiye yönelik olarak aşağıdaki hipotez geliştirilmiştir:

$\mathbf{H}_{4}$ : Çalışanların kişisel başarıda düşme hissi düzeyleri ile işten ayrılma niyetleri arasında pozitif yönlü bir ilişki vardır. 


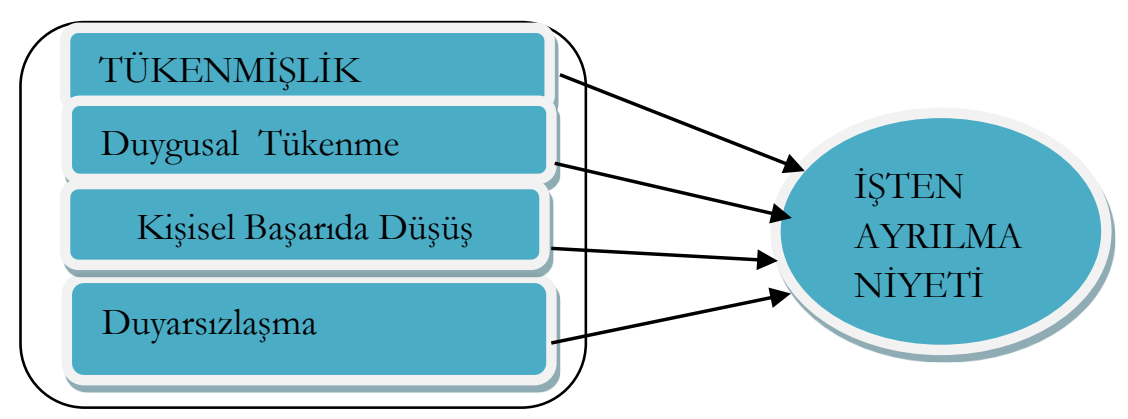

Şekil 1. Araștrma Modeli

Araştırmanın amacı ve hipotezleri doğrultusunda araştırma modeli oluşturulmuştur ve Şekil 1'de verilmiştir. Araştırma modelinde gösterildiği gibi, model bir neden-sonuç ilişkisini ortaya koymaktadır. Duygusal tükenme, duyarsızlaşma ve kişisel başarıda düşüş tükenmişliğin alt boyutları bağımsız değişkenler olarak kabul edilmektedir. İșten ayrılma niyeti ise bir bağımlı değişken olarak belirlenmiştir

\section{Yöntem}

Konaklama işletmelerinde çalışanların işgücü devir oranının yüksek olması konaklama işletmelerinin en önemli sorunlarından birisi sayılmaktadır (Kaya, 2010, s. 220). Türkçe ve yabancı literatürde ilgili bilimsel araştırmalar incelendiğinde, tükenmişlik ve işten ayrılma konularıyla ilgili oldukça fazla çalışmalar olmasına rağmen, Kırgızistan'da bu konu ile ilgili çalışmaların çok sınırlı olduğu ve Kırgızistan'da otel çalışanlarının tükenmişlik düzeyleri ve işten ayrılma niyetlerine ilişkin bir çalışma olmadığı görülmüştür. $\mathrm{Bu}$ çalışma ile Kırgızistan'da otel çalşsanlarının tükenmişlik düzeyleri ve işten ayrılma niyetleri arasındaki ilişkinin tespit edilmesi amaçlanmışır.

Araştırma evrenini Kırgızistan Bişkek şehrinde faaliyet gösteren üç, dört ve beş ylldızlı otel işletmelerinin çalışanları oluşturmaktadır. Araştırmanın gerçekleştirildiği tarihlerde Kırgızistan Kültür, Enformasyon ve Turizm Bakanlığından alınan bilgiye göre Bişkek şehrinde üç, dört ve beş yıldızlı olarak faaliyet gösteren 23 otel işletmesi bulunmaktadır. Bu otellerden dokuz tanesi çalışmaya dahil olmak istemediği için araştırmaya dahil edilmemiştir. Araştırma yedi adet üç yıldızlı, beş adet dört yıldızlı ve iki adet de beş yıldızlı otel olmak üzere toplam 14 konaklama işletmesini kapsamaktadır.

Araştırmanın örneklemini konaklama işletmelerinde görev alan toplam 277 otel çalşsanı oluşturmaktadır. Araştırmaya dahil edilen konaklama işletmelerin insan kaynakları yöneticilerinden elde edilen bilgiye göre, araştırmanın yapıldığı tarihlerde işletmelerde toplam istihdam edilen toplam 301 çalışandan 292'i ile görüşülmüsşür. Anket uygulaması sonucunda 15 adet soru formu hatalı veya eksik olduğu gerekçesiyle araştırmaya dahil edilmemiştir. Kalan 277 anketin tamamı geçerli kabul edilmiş ve analize tabi tutulmuştur. $\mathrm{Bu}$ araştırmada veriler Bişkek şehrinde bulunan otel çalışanları ile sınırlandırılmıştır.

Yapılan araştırmada veri toplama aracı olarak anket formu kullanılmıştır. Anket formu toplam iki bölümden oluşmaktadır. Anketin birinci bölümünde Maslach Tükenmişlik Envateri ile Carson ve diğerleri (1999) tarafından geliştirilen üç maddelik 'işten ayrılma niyeti' ölçeği yer almaktadır, ikinci bölümde çalışanların demografik verileri bulunmaktadır.

Anketin birinci bölümünde soru türü olarak kapalı uçlu sorular, örnekleme çeşitlerinden tesadüfi olmayan örnekleme yöntemlerinden amaca göre örnekleme yöntemi (purposive sampling) tercih edilmiştir. Ölçek olarak tükenmişlik alt boyutlarını ölçmek için Maslach ve Jackson (1981) tarafından geliştirilen ve Ergin (1993) tarafindan Türkçeye çevrilen ve uyarlanan Maslach Tükenmişlik Ölçeği kullanılmıştır (Yücel ve Koçak, 2018, s. 301). Ölçeğin orijinali yedi dereceli Likert tipi ölçektir ama güncel uygulamalarda beşli Likert tipi ölçeğe dönüştürülmüştür (Gökdemir, 2017, s. 136). Bu çalsşmada beşli Likert Ölçeği tercih edilmiştir.

Maslach Tükenmişlik Ölçeği 22 maddeden oluşmaktadır ve tükenmişlik üç boyutta değerlendirilmektedir. Duygusal tükenme boyutunda dokuz soru (1, 2, 3, 6, 8, 13, 14, 16, 20), Kişisel Başarıda Düşüş boyutu sekiz soruyu kapsamaktadır $(4,7,9,12,17,18,19,21)$ ve en son boyutu Duyarsızlaşma boyutunda ise beş soru $(5,10,11,15,22)$ yer almaktadır. İşten ayrılma niyeti ise Carson ve diğerleri (1999) tarafindan geliştirilen 3 maddelik "işten ayrılma niyeti" ölçeği ile ölçülmektedir. 
Katılımciların ankette yer alan her bir ifadeye ait katılım düzeyleri "1=hiçbir zaman .... 5=her zaman" şeklinde Beşli Likert Ölçeği ile derecelendirilmiştir.

Anketin ikinci bölümünde ise katılımcıların demografik özelliklerine cinsiyet, yaş, medeni ve eğitim durumu yer verilmiştir. Bir takım başka özellikler de yer verilmiştir. Bunlar; turizm eğitimi alınıp alınmadığı, çalıştı̆̆ otel sınıfi, konaklama işletmede çalışma süresi, çalıştığı bölüm, statüsü, günlük çalışma süresi-saat ve aylık maaşıdır.

Gerçekleştirilmek istenilen araştırmanın amacına uygun ölçeklerin seçilmesinden sonra anketin ilk örneği Türkçe hazırlanmıştır. Araştırmanın evreni Kırgızistan Bişkek şehrinde faaliyet eden otellerinden oluştuğu ve Kırgizistan'ın resmi dili Rusça olduğu için anket Türkçeden Rusçaya Türkiye Cumhuriyet Büyük Elçiliği bünyesinde çalışan yeminli tercüme bürosunda çevrilmiştir. Veriler Ocak- Mart 2019 döneminde araştırmacı tarafindan otel çalışanlarına yüz yüze anket uygulaması yapılarak toplanmıştır. Araştırmaya katılan otel çalışanlarından elde edilen verilerin analizde sosyal bilimlerde en çok kullanılan SPSS (Statistical Package for the Social Sciences) istatistik paket programından yararlanmıstır. Araştırmanın güvenirlik analizi, faktör analizi, korelasyon ve regresyon analizleri SPSS istatistiksel yazılım yardımıyla yapılmıştır.

\section{Araştırma Bulguları ve Tartışma}

Araştırmaya katılan kişiler ile ilgili demografik verilere ilişkin bilgiler Tablo 1'de yer almaktadır.

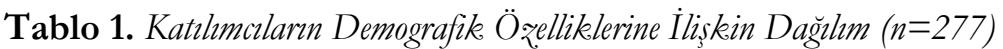

\begin{tabular}{|c|c|c|c|}
\hline Özellikler & Kategoriler & Frekans & Yüzde $(\%)$ \\
\hline \multirow{2}{*}{ Cinsiyet } & Kadın & 143 & 51,6 \\
\hline & Erkek & 134 & 48,4 \\
\hline \multirow{2}{*}{ Medeni Durum } & Evli & 125 & 45,1 \\
\hline & Bekar & 52 & 54,9 \\
\hline \multirow{4}{*}{ Eğitim Durumu } & İlköğretim & 2 & 0,7 \\
\hline & Lise & 103 & 37,2 \\
\hline & Ön lisans- Lisans & 142 & 51,3 \\
\hline & Yüksek Lisans-Doktora & 30 & 10,8 \\
\hline \multirow{2}{*}{ Turizm Eğitim Alıp Almadığ1 } & Evet & 135 & 48,7 \\
\hline & Hayır & 142 & 51,3 \\
\hline \multirow{3}{*}{ Çalıştığ1 Otel Yıldızı } & Beş Yıldızlı & 53 & 19,1 \\
\hline & Dört Yildızlı & 141 & 53,1 \\
\hline & Üç Yildızlı & 77 & 27,8 \\
\hline \multirow{7}{*}{ Çalıştığ 1 Departman } & Ön büro & 70 & 25,3 \\
\hline & Kat Hizmetleri & 56 & 20,2 \\
\hline & Yiyecek-İçecek & 74 & 26,7 \\
\hline & Muhasebe & 30 & 10,8 \\
\hline & Satış-Pazarlama & 11 & 4,0 \\
\hline & İnsan Kaynaklar1 & 20 & 7,2 \\
\hline & Diğer & 16 & 5,8 \\
\hline \multirow{4}{*}{ Çalışma Statüsü } & Daimi & 214 & 77,2 \\
\hline & Geçici (sezonluk) & 16 & 5,8 \\
\hline & Stajyer & 33 & 11,9 \\
\hline & Ekstra Personel & 14 & 5,1 \\
\hline \multirow{5}{*}{ Yaş } & $15-24$ & 122 & 44,0 \\
\hline & $25-34$ & 108 & 39,0 \\
\hline & $35-44$ & 42 & 15,2 \\
\hline & $45-54$ & 4 & 1,4 \\
\hline & 54-üstü & 1 & 0,4 \\
\hline \multirow{5}{*}{ Konaklamada Çalışma Süresi (ay) } & $1-11$ & 57 & 20,6 \\
\hline & $12-23$ & 60 & 21,7 \\
\hline & $24-35$ & 44 & 15,9 \\
\hline & $36-47$ & 47 & 17,0 \\
\hline & 48-üstü & 69 & 24,8 \\
\hline \multirow{3}{*}{ Çalışma Saati } & 8 saat & 95 & 34,3 \\
\hline & 10 saat & 19 & 6,9 \\
\hline & 12 saat & 163 & 58,8 \\
\hline \multirow{5}{*}{ Ücret (KGS) } & $10.000-14.999$ & 53 & 19,1 \\
\hline & $15.000-19.999$ & 71 & 25,6 \\
\hline & $20.000-24.999$ & 75 & 27,2 \\
\hline & $25.000-29.000$ & 45 & 16,2 \\
\hline & 30.000 ve yukar1 & 33 & 11,9 \\
\hline
\end{tabular}


Çalışmaya katılanların demografik yapılarına bakıldığında, otel çalışanlarının kadın-erkek dağılımın neredeyse eşit olduğunu, \%62'sinin üniversite mezunu olduğu, \%51,3'nin turizm eğitimi almadığı, \%77,3'ünün daimi personel olarak çalsştığ1 ve ağırllklı olarak yiyecek-içecek ve ön büro bölümlerinde çalıştıkları tespit edilmiştir. Araştırmaya katılanları ağırlıklı olarak 15-24 yaş aralı̆̆ındaki gençlerin oluşturduğu (\%44), konaklama işletmelerinde ortalama çalışma sürelerinin 3 yil ve otel çalışanlarının ortalama günlük çalışma sürelerinin de 10 saat olduğu görülmüştür. Çalşsanların ortalama gelirleri ise 15.000-19.999 KGS ya da yaklaşık 1.700 TL'dir.

Bu çalışmada otellerde çalışanların tükenmişlik seviyelerini ölçmek için kullanılan toplam 22 maddelik Maslach Tükenmişlik Envanteri ölçeğine ait veriler örneklem ölçüm yeterliği için Kaiser-Meyer-Olkin (KMO) ve Barlett Küresellik Testi yapılmıştır. KMO katsayısının $(0,790)$ açılayıcı faktör analizi için gerekli olan örneklem yeterliliğine sahip olduğunu gösterdiğine ve araştırmanın örneklem büyüklüğün yeterli olduğuna karar verilmiştir. Ki-Kare Değerinin 889,329 ve anlamllık düzeyinin $\mathrm{p}=0.000<0.05$ olması nedeniyle taslak ölçeğe ilişkin elde edilen verilerin faktör analizine uygun olduğu görülmüsstür.

Ölçeğin faktör yapısının incelenmesi amacı ile açıklayıcı faktör analizi yapılmıştır. Açıklayıcı faktör analizi gerçekleştirilirken toplam sekiz maddenin faktör yükünün 0,50 'nin altında, ağırlıklarının binişik ve düşük olduğu tespit edilmiştir. Bu gerekçeyle 1, 4, 8, 9, 10, 13, 20 ve 21 numaralı maddeler modelden tek tek çıkarılmıştır. Kalan 14 madde üzerinden açıklayıcı faktör analizi yapılmıştır. Analiz sonucuna göre toplam üç boyut elde edilmiştir. Bu üç boyutun altında toplanan maddeler ve maddelere ait faktör yüklerini gösteren döndürülmüş bileşenler matrisi (Rotated Component Matrix) Tablo 2'de verilmiştir.

Tablo 2'de gösterildiği gibi döndürme sonrası maddelerin toplam üç boyut altında toplandığ1 ve maddelerin faktör yükü değerlerinin 0,593 - 0,779 aralığında değiștiği görülmektedir. Maddelerin ait olduğu faktörle olan ilişkisini açılayan faktör yük değeri katsayısı için uygulamada genel olarak 0.45 üzeri değerler madde seçimi için iyi bir ölçüt olarak önerilmektedir (Yemez, 2016:109). Birinci boyut beş ifadeden, ikinci boyut beş ifadeden ve üçüncü boyut ise dört ifadeden oluşmaktadır. Literatürde olduğu gibi kişisel başarıda düşüş (KBD), duygusal tükenme (DUT) ve duyarsızlaşma (DUY) olarak isimlendirilmiştir. Elde edilen faktörlere ilişkin diğer bulgular Tablo 3`deki gibidir.

Tablo 2. Tükenmislike Ölçeginin Döndürme Sonrası Faktörler ve Madde Yük Değerleri

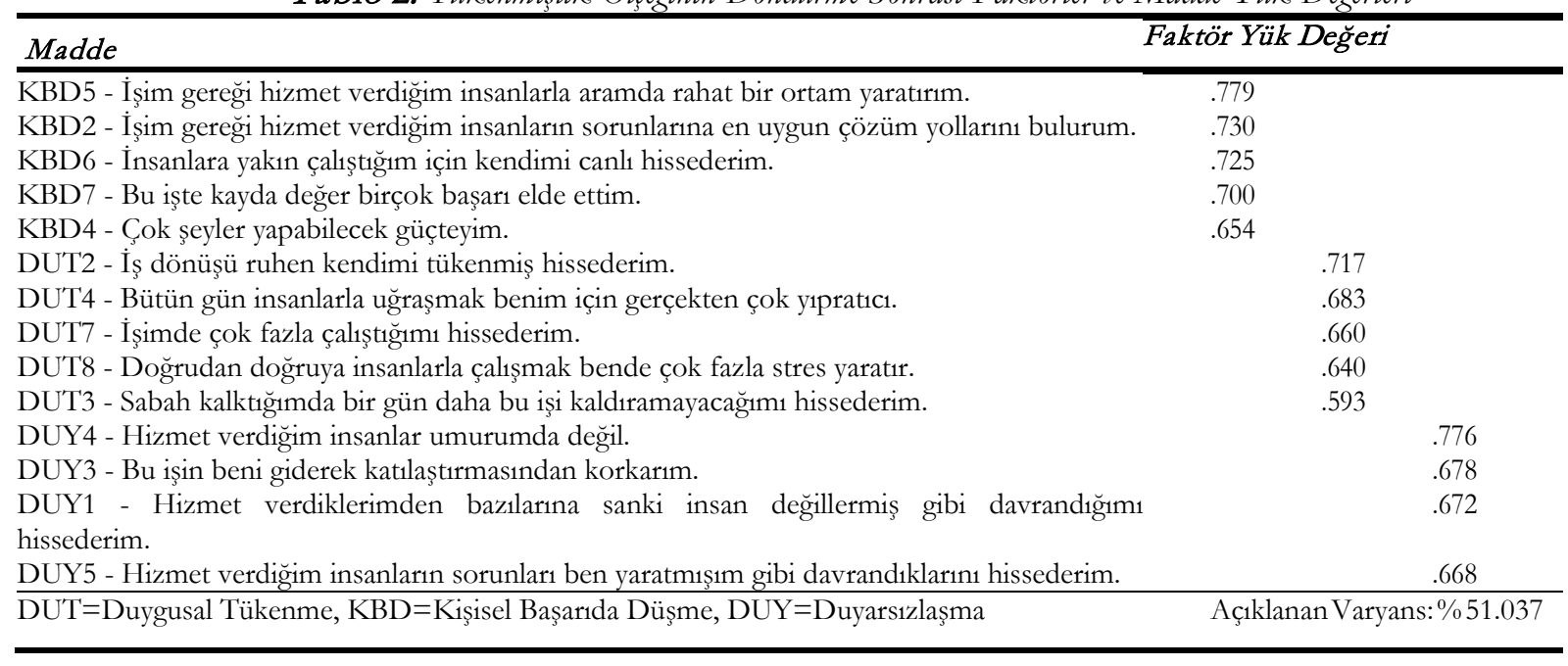

Yapılan faktör analiz sonucuna göre üç boyutun açıkladıkları varyans \% 8,378 ve \% 23,126 arasında değişim göstermektedir. Toplam açıklanan varyansın ise \% 51,037 olduğu tespit edilmiştir. Elde edilen bulgulara göre analiz sonucunda ortaya çıkan üç faktörün birlikte ana yapıya ait toplam varyansın yaklaşık \%50 'sini açıkladığı belirlenmiştir. Bu değer Kline'a göre \% 40'in üzerinde olduğundan dolayı kabul edilebilir düzeydedir (Ceyhan ve Namlu, 2000, s. 86; Yemez, 2016, s. 110).

Tablo 3. Açılelayıc Faktör Analiz̨i Sonuçlar

\begin{tabular}{lccc}
\hline Boyutlat & Özdeğer & Varyans(\%) & Kümülatif Varyans (\%) \\
\hline KBD & 3.238 & 23,126 & 23,126 \\
DUT & 2.735 & 19,533 & 42,659 \\
DUY & 1.173 & 8,378 & 51,037 \\
\hline DUT=Duygusal Tükenme, KBD=Kişisel Başarıda Düşme, DUY=Duyarsılaşma & \\
\hline
\end{tabular}


Güvenirlik testi sonuçlarına göre Cronbach Alpha katsayıları duygusal tükenme için: 0,708, duyarsızlaşma için: 0,707 ve kişisel başarıda düşüş için: 0,772 olarak gözlemlenmiştir. Ayrıca araştırmanın genelinde Cronbach Alpha katsayısi; 0,730 olarak gözlemlenmiştir. İşten ayrilma niyeti için: 0,713 olarak gözlemlenmiştir. Alfa değeri 0 ile 1 arası değerler alır ve kabul edilebilir bir değerin en az 0,7 olması arzu edilir (Altunışık, Coşkun ve Yıldırım, 2007, s. 116). Bu durumda araştırmada tükenmişliğin bütün boyutlarında ve işten ayrılma niyetinde güvenirlik katsayılarının 0,70'ten büyük olduğu ve verilerin güvenilirliğinin kabul edilebilir düzeyde olduğu görülmektedir.

Çalışmadaki işten ayrılma bağımlı değişkeni ile bağımlı değişken üzerinde etkisi olduğu varsayılan tükenmişlik bağımsız değişkeni arasındaki ilişkinin açıklanmasına yönelik regresyon analizi yapılmıştır. Değişkenler arasındaki ilişkileri inceleyen ve değişkenlerin birbiri üzerinde etkisinin olup olmadığını gösteren regresyon analizi (Yılmaz, 2014, s. 79) öncesi bağımsız değişkenler arasında çoklu bağlantı sorunu (multicollinearity) olup olmadığı test edilmiştir. Bağımsız değişkenler arasındaki çoklu bağlantı sorunun olup olmadığı anlamak için varyans artış faktörlerine ve tolerans değerlerine bakılmıştır. Araştırmanın bağımsız değişkenlerine ait varyans artış faktörleri (variance inflation factor - VIF) ve tolerans değerleri incelendiğinde, tolerans değerlerinin 1,000, varyans artış faktörlerinin 1,000 olduğu saptanmıştır. Dolayısıyla değişkenler arasında çoklu bağlantı sorununun olmadığ1 (Büyükuysal ve Öz, 2016, s. 111; Etyemez, 2013, s. 69) ortaya konmuştur

Ölçeklerin normal dağılım gösterip göstermediğine dair en güçlü testlerinden olan KolmogorovSmirnov ve Shapiro-Wilk testleri uygulanmıştır (Razali ve Wah, 2011, s. 23). Tabachnick ve Fidell, çarpıklık ve basıklık değerlerinin $+1,500$ ve $-1,500$ değerleri arasında olduğu durumlarda dağılımın normal dağılım olarak gerçekleştĭgini kabul etmektedirler (Tabachnick ve Fidell. 2013). Yapılan normallik testi sonucunda sonuçların normal dağılım göstermesi nedeniyle parametrik (Parametric) testler yapılmıştır.

Tükenmişlik ve işten ayrılma niyeti ilişkisinin test edilmesine yönelik yapılan regresyon analiz sonuçlarına (tablo 4) bakıldığında, $\mathrm{F}$ değerinin $(48,265)$ anlamlılık seviyesi $\mathrm{p}<0,05$ olarak bulunduğu için anlamlı olduğu yorum yapılabilir. $\mathrm{R}$ değeri ile aynı değere sahip olan beta katsayısına $(, 386)$ bakıldığında tükenmişlik ile işten ayrilma niyeti arasında bir ilişkinin olduğu söylenebilir. Uyarlanmış R2 değerine göre bağımsız değişken olan tükenmişlik, bağımlı değişken olan işten ayrılma niyetinde değişimin $\% 14,6^{\natural} \mathrm{l} k \mathrm{k}$ kısmını açıkladığı söylenebilir. Dolayısıyla, bu bulgu tükenmişliğin işten ayrılma niyeti üzerinde etkisinin olduğunu göstermektedir. İlişkisi vardır şeklinde yorumlanabilir.

Ayrıca yapılan diğer analizlerde Bişkek'teki otellerde çalışanların işten ayrılma niyeti üzerinde tükenmişliğin alt boyutları olan duygusal tükenme boyutunun $(\beta=0,338, \mathrm{p}<0,01)$, kişisel başarı boyutunun $(\beta=0,51, \mathrm{p}<0,01)$ ve duyarsızlaşma boyutunun $(\beta=0,423, \mathrm{p}<0,01)$ etkili olduğu tespit edilmiştir.

Tablo 4. Genel Tükenmişlïgin İsten Ayrlma Niyeti Üžrindeki Etkisini Açıklayan Regresyon Analiẓ sonuçlar

\begin{tabular}{|c|c|c|c|c|c|}
\hline & \multicolumn{2}{|c|}{$\begin{array}{c}\text { Standardize Edilmemis } \\
\text { Katsayılatı }\end{array}$} & \multirow{2}{*}{$\begin{array}{c}\text { Standardize Edilmis } \\
\text { Katsayılant } \\
\text { Beta }\end{array}$} & \multirow[t]{2}{*}{$t$} & \multirow[t]{2}{*}{$\begin{array}{l}\text { Anlam } \\
\text { Düzeyi }\end{array}$} \\
\hline & $B$ & Std. Hata & & & \\
\hline (Sabit) & 0.679 & 0.228 & & 2.980 & 000 \\
\hline Tükenmișlik & 0.604 & 0.087 & 0.386 & 6.947 & 009 \\
\hline \multicolumn{6}{|c|}{ Bağımlı Değişken: İșten Ayrılma; $\mathrm{R}=0.386 ; \mathrm{R}^{2}=0.149 ; \mathrm{F}=48.265, \mathrm{p}<.00$} \\
\hline
\end{tabular}

$\mathrm{Bu}$ çalışmanın hipotezlerini sınamak için değişkenler arasındaki ilişkileri test etmek amacıyla korelasyon analizi yapılmıştır (Tablo 5). Genellikle korelasyon katsayısı 0,85 ile 1 ise değişkenler arasında çok güçlü bir ilişki, katsayı 0,65 ile 0,84 arasında ise değişkenler arasında yüksek bir ilişki, katsayı 0,30 ile 0,64 ise orta düzey ilişki ve 0 ile 0,29 arası ise düşük/zayıf bir ilişki olduğu kabul edilmektedir (Yılmaz, 2014, s. 78). Bişkek'teki konaklama işletmelerinde çalışanların genel tükenmişlik düzeyleri ile işten ayrılma niyeti arasında orta düzeyde istatiksel olarak pozitif yönlü bir ilişki $(r=, 386 ; \mathrm{p}<0,001)$ olduğu görülmüştür. Gerçekleştirilen korelasyon analizi neticesine göre hipotez 1 desteklenmiştir.

Tablo 5. Tükenmişlik ve İsten Ayrlma Niyeti Arasındaki Korelasyon

\begin{tabular}{lcc}
\hline & İşten Ayrılma Niyeti & Tükenmişlik \\
\hline İșten Ayrılma Niyeti & 1 & $.386^{* *}$ \\
Tükenmişlik & $.386^{* *}$ & 1 \\
\hline
\end{tabular}

Tükenmişliğin alt boyutları ile işten ayrılma niyeti arasındaki ilişkiye yönelik yapılan korelasyon analizi sonuçlarına bakıldığında (Tablo 6) herhangi bir ters yönlü ilişkinin olmadığı görülmüştür. Duygusal 
tükenme ve duyarsızlaşma boyutlarının pozitif ya da doğru yönlü ilişkide olduğu sonucuna varılmıştır. İşten ayrılma niyeti ile kişisel başarıda düşüş boyutu arasında ise istatiksel olarak anlamlı bir ilişki olmadığ1 tespit edilmiştir. Çalışmaya katılan otel çalışanlarının duygusal tükenmişlik düzeyleri ile işten ayrılma niyeti $(\mathrm{r}=, 338 ; \mathrm{p}<0,001)$ ve duyarsılzlaşma düzeyleri ile işten ayrılma niyeti arasında $(\mathrm{r}=, 423 ; \mathrm{p}<0,001)$ pozitif yönlü orta düzey istatistiksel olarak anlamlı bir ilişki olduğu belirlenmiştir. Otel çalışanlarının kişisel başarıda düşme hissi düzeyleri ile işten ayrilma niyetleri arasında ise $(r=, 051 ; p<0,001)$ istatiksel olarak anlamlı bir ilişki bulunamamıştır. Dolayısıyla yapılan korelasyon analizine göre istatistiki olarak hipotez 2 ve 3 de desteklenirken hipotez 4 desteklenmemiştir.

Tablo 6. Tükenmişlik. Alt Boyutlar ve İsten Ayrlma Niyeti Arasmdaki Korelasyonlar

\begin{tabular}{|c|c|c|c|c|}
\hline & $\begin{array}{c}\text { Kişisel Başarıda } \\
\text { Düşüş }\end{array}$ & $\begin{array}{c}\text { Duygusal } \\
\text { Tükenmişlik }\end{array}$ & Duyarsızlaşma & $\begin{array}{c}\text { İşten Ayrilma } \\
\text { Niyeti }\end{array}$ \\
\hline Kişisel Başarıda Düşüş & 1.0 & & & \\
\hline Duygusal Tükenme & -.078 & 1.0 & & \\
\hline Duyarsızlaşma & $.160^{* *}$ & ,441** & 1.0 & \\
\hline İșten Ayrılma Niyeti & .051 & $.338 * *$ & $.423 * *$ & 1.0 \\
\hline
\end{tabular}

Literatürde mevcut olan çalışmalara bakıldığında tükenmişliğin alt boyutları ve işten ayrılma niyeti ilişkine ilişkin çok fazla çalışmanın olmadığı görülmüştür. Yıldırım vd. (2014) çalışmasında tükenmişliğin alt boyutlarından duygusal tükenme, duyarsızlaşma ve kişisel başarıda düşüş boyutları ile işten ayrılma niyeti arasında bir ilişki bulamamıştır. Onay ve Kılcı (2011) yaptıkları çalışmada tükenmişliğin alt boyutu olan duygusal tükenme ve işten ayrllma niyeti arasında pozitif yönlü bir ilişki saptanmıştır. Ancak duyarsızlaşma boyutu ile işten ayrılma niyeti arasında istatistiki anlamlı bir ilişkiye rastlanmamıştır. Aslan (2014) tükenmişliğin duygusal tükenme boyutu ile işten ayrılma niyeti arasında yüksek derecede ilişki bulmuştur. Duyarsızlaşma boyutunda da orta derecede bir ilişki tespit etmiştir. Aslan ve Etyemez (2015) otel çalışanlarının üzerinde yaptıkları araştırmada, tükenmişliğin duygusal tükenme, duyarsızlaşma ve kişisel başarılda düşüş boyutlarının ve işten ayrılma niyeti arasında anlamlı ilişkilerinin olduğunu tespit etmişlerdir. Çalışkan ve Pekkan (2019) da çalışmalarında tükenmişliğin üç boyutuyla işten ayrrlma niyeti arasında istatistiksel olarak anlamlı ve pozitif bir ilişki olduğunu belirlemişlerdir. Yapılan çalısmaların sonuçlarına bakıldığında da bu çalışmanın sonuçlarına benzer bulguların olduğu ancak, çalışmalarda farklı alt boyutların işten ayrılma niyeti ile anlamlı ilişkisinin olmadığı tespit edilmiştir. Dolayısıyla, konaklama sektörü başta olmak üzere tükenmişliğin alt boyutlarının işten ayrılmaya etkisini belirlemeye yönelik daha fazla çalışmaya ihtiyaç olduğu çok açıtır.

\section{Sonuç ve Öneriler}

Örgütler için işten ayrılma konusu oldukça önemli sorunlarında biri olarak görülmektedir. Yetişmiş, deneyimli ve kalifiye bir çalışanın işten ayrılması, örgüt için hem maliyetli hem de istenmeyen bir durumdur. Bu nedenle işten ayrıma niyeti konusu birçok araştırmacı ve yöneticinin dikkatini çekmiştir ve şimdiye kadar konuya ilişkin birçok çalışma yapılmıştır. Bir otel çalışanın işten ayrılma niyetinde olması ya da işten ayrilma düşünce içinde olması kesin olarak işten ayrllacağı anlamına gelmemektedir. Fakat işverenler için işten ayrılma davranışında bir işaret olarak kabul edilmektedir. İşten ayrılma niyetinin önceden tespit edilmesi ve eyleme geçmemiş olması, işverenler için bir firsat olarak görülebilir ve işten ayrılmaya neden olan kaynakların ortadan kaldırılmasına yönelik tedbirler alınabilir.

Tükenmişlik ve işten ayrılma niyeti birçok araştırmacının dikkatini çekmiştir. İlgili konularla çalışmalar yapılmış ve öneriler sunulmuştur. Araştırmalar farklı endüstri ve sektörlerinin üzerinde yapılmıştır. Otel çalışanlarında tükenmişlik ve işten ayrılma niyetine etkisi ile ilgili Türkiye'de bilimsel çalışmalar mevcut iken, Kırgızistan'da bu konuda bir araştırmaya rastlanmamıştır. Bu araştırmada Kırgızistan Bişkek şehrindeki otel çalışanlarının tükenmişlik düzeyleri ile işten ayrılma niyeti arasındaki ilişsi belirlenmeye çalışılarak, Başta Kırgızistan olmak üzere ilgili literatüre katkı sağlanması amaçlanmıştır.

Araştırma eşit sayıda erkek ve kadının katıldığı gözlemlenmiştir. Bu bulgudan yola çıkararak Kırgızistan'ın Bişkek şehrinde, turizm sektöründe düzensiz çalışma saatlerine, işin zorluğuna ve yoğunluğuna rağmen kadınların da en az erkekler kadar sektörü tercih ettiği görülüyor.

Ankete katılanların büyük çoğunluğu genç ve orta yaş otel çalışanlarından oluşmaktadır. 45 yaş üstü otel çalsşanlarının çok az olmasının çeşitli sebepleri olabilir. Bu sebeplerden bazıları; turizm sektöründe müşteri ilişkilerin yoğun ve stresli olması, işin çok yorucu olması ve sezonluk olmasıdır. Ayrıca çalışma saatlerin uzun olması da bu sebeplerinden biri olarak görülebilir. Araştırmada ankete katılan otel 
çalışanlarının günlük çalışma sürelerin ortalama 10 saat olduğu görülmüştür. Çalışma saatlerinin uzun ve bazı durumlarda vardiyalı olması insanların ailelerinden uzak kalmasına sebep olabilmektedir. Dolayısıyla, daha genç yaş grubunun bu şartlarda işe daha kolay adapte olabildiği öne sürülebilir.

Katıllımclların büyük çoğunluğunun lisans-önlisans eğitimine sahip olduğu görülmüştür. Buradan yola çıkarak otel çalışanlarının eğitim seviyesinin yüksek olduğu söylenebilir. Ancak otelde çalışanların çoğunluğunun turizm eğitimi almadığ1 görülmüştür. Görülüyor ki Bişkek'te turizm eğitimi almıs kişilerin otellerde daha fazla istihdam edilmesine gereksinim vardır ve kaliteli turizm hizmetleri için zorunludur.

Araştırmada elde edilen diğer bir sonuç da otel çalışanlarının ortalama gelirlerin 15.000-19.999 KGS (Kırgızistan Milli Para Birimı) ya da araştırma yapıldığı dönem itibari ile ortalama 1.700 TL olmasıdır. Bu gelir Kırgızistan şartlarına göre ortalama bir gelirin olduğunu göstermektedir. Anketi cevaplayanların çoğunun mevcut konaklama işletmelerinde 2-3 yll arası çalışması da konaklama işletmelerinde çalışanlarının devir hızının yüksek olduğuna işarettir. Stresi çok olan bu meslekte gelirlerin ortalama düzeyde olması, çalışanlarının işgücü devir hızı oranın yüksek olmasının nedenlerinden birisi olarak değerlendirilebilir.

Analiz sonuçlarına göre tükenmişlik işten ayrılma niyetini etkilemektedir. Tükenmişlik alt boyutları olan duygusal tükenmenin, duyarsızlaşmanın ve kişisel başarıda düşüşün de işten ayrılma niyetini etkilediği tespit edilmiştir. Bulgulara göre tükenmişlik artarken işten ayrılma niyetinin de artığı söylenebilir. Bu nedenle otel yöneticilerinin meydana gelebilecek tükenmişliği önlemek için çalsşmalar yapması gerektiği anlaşılmaktadır. Bu kapsamda ortalama çalışma süresi olan 10 saatin makul uluslararası standart olan günlük sekiz saatle sınırlandırılmasıyla tükenmişliğin azalmasına destek verilecektir.

Gerçekleştirilen araştırma sonuçları, üç açıdan önemli ve faydalı görülmektedir: Birinci olarak; Kırgızca kaynaklarda konu ile ilgili araştırmaların çok kısıtlı olduğu hem de konaklama işletmelerine yönelik olarak yapıldığından dolayı, ilgili literatürdeki boşluğu doldurmakta ve literatüre önemli katkı sağlamaktadır. İkinci olarak; Kırgızistan'da konaklama işletmelerinde çalışanlarının tükenmişlik düzeylerinin işten ayrilma niyeti üzerindeki etkisinin ortaya konulması bakımından önemli bir katkı sağlamaktadır. Üçüncü olarak ise araştırma, turizm sektöründeki işten ayrllma niyetini ortadan kaldırma/önleme ve yüksek düzeyde işgücü devir oranını düşürme gibi sorunların çözümüne bir aracı olarak ışık tutmaktadır.

Araştırma sonuçları sadece araştırma yapılan ülkenin bir şehri içinde olan konaklama işletmeleri ile sınırlıdır. Sonuçlar, Kırgızistan bütün konaklama işletmeleri için geçerli olamaz. Yapılan bu çalışma sadece Kırgızistan Bişkek şehrinde beş, dört ve üç yıldızlı otel çalışanlarına uygulanan anket verilerine dayanmaktadır. Elde edilen bu sonuçların daha genellenebilir olması için hem aynı sektördeki hem de farklı sektörlerdeki daha fazla otel çalışanına uygulanması gerekmektedir. Bu araştırmanın benzeri başka şehirler için konaklama işletmelerinde ya da diğer turizm işletmelerinde uygulanabilir. Kırgızistan genelinde Turizm sektörünün tamamı için durum tespiti yapılabilir. Tükenmişlik konusu, farklı illerde stres, iş tatmini gibi farklı değişkenlerle de incelenebilir.

\section{Etik Beyan}

"Otel Çalısanlarnda Tükenmişlik ve İsten Ayrlma Niyetine Etkisi: Biş̧kek'te Bir Araştırma" başlıklı çalışmanın yazım sürecinde bilimsel kurallara, etik ve alıntı kurallarına uyulmuş; toplanan veriler üzerinde herhangi bir tahrifat yapılmamış ve bu çalışma herhangi başka bir akademik yayın ortamına değerlendirme için gönderilmemiştir. Bu araştırma, 01.01.2020 tarihinden önce yapıldığı için etik kurul kararı zorunluluğu taşımamaktadır.

\section{Kaynakça}

Adoum, S. Y. (2017). Süleyman Demirel Üniversitesi'nde okuyan yerli ve yabanc ögrencilerin tükenmişlik düreylerinin belirlenmesi (Yüksek Lisans Tezi) Süleyman Demirel Üniversitesi Sosyal Bilimler Enstitüsü, Isparta.

Altunışı, R. Coşkun, R. ve Yıldırım, E. (2007). Sosyal bilimlerde araștırma yöntemleri, SPSS uygulamalı. Sakarya: Sakarya Yayincilik.

Ardıç, K., ve Polatçı S. (2008). Tükenmişlik sendromu: Akademisyenler üzerinde bir uygulama. Gą̧i Üniversitesi İktisadi ve İdari Bilimler Fakültesi Dergisi 10(2), 69-96.

Aslan, Z. (2014). İşgörenlerin tükenmişlik düzeylerinin işten ayrılma niyeti üzerine etkisi: İstanbul'daki seyahat acentalarında bir araştırma. Nevşehir Hacı Bektaş Veli Üniversitesi Sosyal Bilimler Enstitüsü Dergisi, 3, 19-40. 
Aslan, Z ve Etyemez, S. (2015). İşgörenlerin tükenmişlik düzeylerinin işten ayrılma niyeti üzerine etkisi: Hatay'daki otel işletmelerinde bir araştırma. Işletme Araştırmalar Dergisi, 7(3), 482-507.

Austen, S. ve Jefferson, T. (2016). Work ability, age and intention to leave aged aare work, Australian Journal on Ageing, 35(1), 18-22.

Birdir, K. ve Tepeci, M., (2003). Otel genel müdürlerinde tükenmişlik sendromu ve tükenmişliğin genel müdürlerin işlerini değiştirme eğilimlerine etkisi. Anatolia Turiz̧m Araştırmalar Dergisi, 14/2, 93-106.

Büyükuysal, M.Ç. ve Öz, İ.I. (2016). Çoklu doğrusal bağıntı varlığında en küçük karelere alternatif yaklaşım: Ridge regrasyon, Düzce Üniversitesi Sağhlk Bilimleri Enstitüsü Dergisi, 6(2), 110- 114.

Cemaloğlu, N. ve Kayabaşı Y. (2007). Öğretmenlerin tükenmişlik düzeyi ile sınıf yönetiminde kullandıkları disiplin modelleri arasındaki ilişki. Gą̧i Eğitim Fakültesi Dergisi, 27(2), 123-155.

Cerdin, J. L. ve Pargneux, M. L. (2014). The impact of expatriates' career characteristics on career and job satisfaction, and intention to leave: An objective and subjective fit approach. The International Journal of Human Resource Management, 25:14, 2033-2049.

Ceyhan, E. ve Namlu, A.G. (2000). Bilgisayar kayg1 ölçeği (BKÖ): Geçerlik ve güvenirlik çalışması. Anadolu Üniversitesi Ë̆itim Fakültesi Dergisi, 10(2), 77-93.

Çalışkan, A. ve Pekkan, N.U. (2019). Sağlık sektörü çalışanlarında tükenmişlik duygusunun işten ayrılma niyetine etkisi: Kişi-örgüt uyumunun arac1lı rölü. Business And Economics Research Journal, 10(2), 469-481.

Çam, O. (1995). Tükenmişlik. İzmir: Saray Medikal Yayıncılık.

Elangovan, A. R. (2001). Causal ordering of stress, satisfaction and commitment, and intention to quit: A structural equations analysis. Leadership and Organizational Development Journal, 22 (4), 159-165.

Etyemez, S. (2013). İşgörenlerin tükenmişlik düzeylerinin işten arılma niyeti üzerine etkisi: Hatay'daki otel işletmelerinde bir araştırma. Nevşehir Üniversitesi Sosyal Bilimler Enstitüsü dergisi, Nevşehir.

Goodwin, R. E., Groth, M., ve Frenkel, S.J., (2011). Relationships between emotional labor, job performance, and turnover. Journal of Vocational Behavior 79 (2), 538-548.

Gökdemir, S. (2017). Turist rehberlerinde is doyumu ve tükenmişlik ilişkisi: Bir alan araștırması (Doktora Teai). Balıkesir Üniversitesi Sosyal Bilimler Enstitüsü, Balıkesir.

Izgar, H. (2003). Okul yöneticilerinde tükenmislike nedenleri, sonuçlar ve başa çıkma yolları. Ankara: Nobel Yayın Dağıtım.

Jackson, S.E. ve Maslach, C. (1982), "After-effects of job-related stress: families as victims", Journal of Occupational Behaviour, Vol. 3, 63-77.

Jackson, S.E., Schwab, R.L. ve Schuler, R.S. (1986), "Toward an understanding of the burnout phenomenon", Journal of Applied Psychology, Vol. 71, 630-40.

Kaçmaz, N. (2005). Tükenmişlik (Burnout) sendromu. İstanbul Tipp Fakültesi Dergisi, 68(1), 29-32.

Kaya, Ş.O. (2010). Ankara ilinde çalşsan polislerin tükenmislik düzeylerinin bą̧ değişkenler açısından incelenmesi. (Yüksek Lisans Tezi), Çukurova Üniversitesi Sosyal Bilimler Enstitüsü, Adana.

Kervanc1, F. (2013). Tükenmislike sendromunun örgütsel bağhllk ve ișten ayrlma niyetine etkisini belirlemeye yönelik bir araștırma. (Yüksek Lisans Tezi) Niğde Üniversitesi Sosyal Bilimler Enstitüsü, Niğde.

Maslach, C. ve Jackson S.E. (1981). The measurement of experienced burnout. Journal of Occupational Behaviour, 12, 99113.

Ok, S. (2002). Banka çalışanlarının tükenmişlik düzeylerinin iş doyumu, rol çatışması, rol belirsizliği ve bazı bireysel özelliklere göre incelenmesi. Türk Psikolojik Danısma ve Rehberlik Dergisi, 3(21), 57-67.

Onay, M. ve Kılcı, S. (2011). İş stresi ve tükenmişlik duygusunun işten ayrılma niyeti üzerine etkileri: Garsonlar ve aşçıbaşılar. Organizasyon ve Yönetim Bilimleri Dergisi, 3(2), 363-372.

Osmanoğlu Taştan, N. (2015). Mobbing (psikolojik şiddet) Algisı, tïkenmislik sendromu ve işten ayrlma niyeti arasindaki ilişki: Banka çalş̧anlar üzerinde bir araştırma. (Yüksek Lisans Tezi), Beykent Üniversitesi Sosyal Bilimler Enstitüsü, İstanbul.

Öztürk Çiftçi, D., Meriç, E ve Meriç, A. (2015). Örgütsel sessizlik, tükenmişlik ve işten ayrılma niyeti ilişkisi: Ordu ili özel eğitim ve rehabilitasyon merkezlerinde bir uygulama. Uluslararası Sosyal Arastırmalar Dergisi, 8(41), 996-1007.

Price, J.L. ve Mueller, C.W. (1986) Absenteeism and turnover among hospital employees. JAI Press, Greenwich.

Razali, N. M. ve Wah, Y.B. (2011). Power comparisons of Shapiro-Wilk, Kolmogorov-Smirnov, Lilliefors and Anderson-Darling tests. Journal of Statistical Modeling and Analytics, 2(1), 21-33.

Sağlam Arı, G. ve Çına Bal E. (2008). Tükenmişlik kavramı: Birey ve örgütler açısından önemi. Yönetim ve Ekonomi Dergisi (Celal Bayar Üniversitesi İ.̇.B.F.), 15(1), 131-148.

Sağlam Arı, G., Bal, H. ve Çına Bal, E. (2010). İşe bağllı̆̆ın tükenmişlik ve işten ayrılma niyeti ilişkisindeki aracılık etkisi: yatırım uzmanlar üzerinde bir araştırma. Süleyman Demirel Üniversitesi İktisadi ve İdari Bilimler Fakültesi Dergisi, 15(3), 143-166.

Schaufeli, W. B. ve Bakker, A. B. (2004). Job demands, job resources, amd their relationship with burnout and engagement: a multi sample study. Journal of Organizational Study, 25, 293-315.

Sürgevil Dalkılıç, O. (2014). Calıs̆ma hayatında tükenmişlik sendromu. Ankara: Nobel Akademik Yayıncılık, 2. Baskı.

Ulutaş, Ö. (2015). Otel işletmelerinde etike iklim algzlamalarmın ve duygusal emeğin tükenmişlik üzerine etkileri: Nevşehir örneği. (Yüksek Lisans Tezi). Nevşehir Hacı Bektaş Veli Üniversitesi Sosyal Bilimler Enstitüsü, Nevşehir.

Sweeney, J. T. ve Summers, S. L. (2002). The effect of the busy season workload on public accountants' job burnout. Behavioral Research in Accounting, 14, 223-245. 
Üngüren, E., Doğan, H., Özmen, M. ve Tekin, Ö. A. (2010). Otel çalışanlarının tükenmişlik ve iş tatmin düzeyleri ilişkisi. Journal of Yasar University, 17(5), 2922-2937.

Veloutsou, C. ve Lewis, J. W. ve Paton, R. A. (2004). University selection: Information requirements and importance. The International Journal of Educational Management, 18(3), 160-171.

Weisberg, J. (1994). Measuring workers burnout and intention to leave. International Journal of Manpower, 15(1), 4-14.

Yemez, İ. (2016). Doğrulayıcı faktör analizi ile sosyal medya reklamlarına yönelik tutum ölçeğinin yap1 geçerliliğinin incelenmesi: Cumhuriyet Üniversitesi İİBF’de bir uygulama. C.Ü. İktisadi ve İdari Bilimler Dergisi, 17(2), 97-118.

Yıldırım, M. H., Erul, E. E. ve Kelebek, P. (2014). Tükenmişlik ile İşten ayrılma niyeti arasındaki ilişki banka çalışanları üzerine bir araştırma. Organizasyon ve Yönetim Bilimleri Dergisi, 6(1), 34-44.

Yılmaz, E. (2014). Duygusal emeğin tükenmişlik ve işten ayrlma niyeti üzerine etkisi: Algzlanan örgütsel desteğin biçimlendirici rolü (Yüksek Lisans Tezi). Çanakkale Onsekiz Mart Üniversitesi Sosyal Bilimler Enstitüsü, Çanakkale.

Yücel, İ. ve Koçak D. (2018). İş tatmini ve işten ayrılma niyeti arasındaki ilişkide tükenmişliğin aracılık etkisi: Sağlık sektöründe bir çalışma. Manas Sosyal Araștıra Dergisi, 7(2), 297-321.

\section{EXTENDED ABSTRACT}

The burnout syndrome is a condition that can be observed in any area of an individual's life. It manifests itself at vast in the tourism sector in particular, due to the intense customer relations and simultaneous production and consumption factor. Employee voluntary resignation rates highly affect the efficacy of the accommodation enterprises, which represent an important share in the tourism sector and are also known to have a higher turnover rate. This prompts the hotel management teams to detect and prevent the burnout syndrome among employees, eliminating the reasons for voluntary resignation. The main purpose of this study is to investigate the effect of the burnout syndrome and the tendency for voluntary resignation at hotels in Bishkek, Kyrgyzstan. Four hypotheses have been developed, through a detailed review and analysis of relevant published sources on the topic. Data has been obtained from 277 hotel employees at three, four and five star hotels via survey. The data obtained from the survey has been studied, and the following analyses have been made: percentage and frequency analysis, factor analysis, correlation, regression, $\mathrm{T}$ Test and ANOVA analysis.

Equal number of men and women participated into research. In Bishkek, Kyrgyzstan, women appear to choose the tourism sector as much as men do despite irregular work hours, difficulty of job and work load in the sector. Majority of participants of questionnaire were young and middle-age hotel workers. There might be several reasons why there were very few hotel employees over the age of 45 years. Some of these reasons are that customer relations are dense and stressful in the tourism sector, the work demands high amount of labor and it is seasonal. In addition, long work hours might be one of these reasons. In the research, daily work hours of hotel workers participated into the questionnaire was approximately 10 hours. Long work hours and working in shifts in certain circumstances cause people to be far away from their family. Therefore, younger age groups can be more easily adapt to such conditions.

Most of the participants had a bachelor's degree or associate degree. Based on this, education level of hotel workers appears to be high. However, majority of hotel workers did not receive tourism education. As is seen, it is necessary to employ persons more who are trained in tourism in hotels in Bishkek, and this is essential for a quality tourism service.

Another result from the research was that average income of hotel workers was 15 000-19 999 SOM (National Currency of Kyrgy:stan) or 1700 TL in average. This figure indicates that there is an average income based on the conditions of Kyrgyzstan. In this profession with higher stress, average level of income might also be one of the reasons for a higher labor turnover of workers. 2 to 3-year service period of majority of responders in the current accommodation establishments also indicates a higher turnover of workers in the accommodation establishments. Some of the reasons why labor turnover is high are that customer relations in the accommodation establishments are very busy, the work hours are long and holidays are shorter.

Based on the results of the descriptive factor analysis, the statements on the burnout inventory are grouped into three dimensions: emotional burnout, depersonalization and low personal achievement. The intent of hotel workers to leave job was measured by three statements.

The regression analysis was performed to determine the impact of variable on each other after descriptive factor analysis. Based on the regression analysis results, burnout affected the intent to leave job. Emotional burnout, one of the sub-dimensions of burnout, had an impact on the intent to leave job. Similarly, it was found that depersonalization, one of the sub-dimensions of burnout, had an impact on 
the intent to leave job. It was observed that low personal achievement (the third sub-dimension) affected the intent to leave job. Therefore, hotel managers need to take action to avoid any possible burnout.

A correlation analysis was performed to identify the correlations between the variables. Based on the analysis results, there was a positive correlation between the general burnout and the intent to leave job. There was a statistically significant positive correlation between the emotional burnout and depersonalization, the sub-dimensions of burnout and the intent to leave job. There was no correlation between the low personal achievement and the intent to leave job. Based on these results, the intent to leave job was increased by the increased burnout.

The research reveals a statistically significant relationship between the employees' burnout levels and their tendencies for voluntary resignation. Herewith, the hypothesis of the three sub-groups of the burnout syndrome that is emotional exhaustion, inefficacy and cynicism influencing the resignation rates has also been examined; of which two were found to affect the resignation rates. A positive correlation has been found between the factor of emotional exhaustion and resignation rates. Likewise, cynicism or depersonalization levels proved to have an influence on the overall tendencies to quit, while no statistically significant relation has been found between the decrease in the personal accomplishment and resignation rates.

The results of this research can be important and useful in three aspects. First, there were a limited number of researches in the Kyrgyz literature on this matter as well as the current studies were performed for the accommodation establishments, therefore, this research fills the gap in the relevant literature and makes a significant contribution to the literature. Second, it makes an important contribution to show the impact of levels of burnout of workers in the accommodation establishments on the intent to leave job in Kyrgyzstan. Third, the research will provide data to assist hotel managers in reducing their tendencies for voluntary resignation in Bishkek hotels and in reducing the high turnover ratio of hotel employees. 